\title{
POE: Bioclimatic design for sustainability
}

\author{
Hazreena Hussein ${ }^{1}$, Adi Ainurzaman Jamaludin² \\ 1 Department of Architecture, Faculty of Built Environment, \\ 2 Institute of Biological Sciences, Faculty of Science, \\ University of Malaya, 50603 Kuala Lumpur, Malaysia \\ reenalambina@um.edu.my, adiainurzaman@um.edu.my
}

\begin{abstract}
Post Occupancy Evaluation (POE) by using a set of questionnaire was conducted to assess the perception and comfort level required by residents in a college building with the best practice of bioclimatic design strategies. The survey was based on a five-point Likert scale, covering various performance criteria of the building (architectural elements, thermal comfort, indoor air quality, visual comfort, acoustic comfort and landscape features). The positions of the rooms should be highly considered in implementing the improvement measures for increasing the comfort level of the room when this aspect considerably influences the satisfaction and perception levels of respondents.

Keywords: bioclimatic design, Likert scale, post- occupancy evaluation (POE), residential college building.

eISSN 2398-4295 @ 2018. The Authors. Published for AMER ABRA cE-Bs by e-International Publishing House, Ltd., UK. This is an open-access article under the CC BY-NC-ND license (http://creativecommons.org/licenses/bync-nd/4.0/). Peer-review under responsibility of AMER (Association of Malaysian Environment-Behaviour Researchers), ABRA (Association of Behavioural Researchers on Asians) and $c E-B s$ (Centre for EnvironmentBehaviour Studies), Faculty of Architecture, Planning \& Surveying, Universiti Teknologi MARA, Malaysia.
\end{abstract}

DOI: http://dx.doi.org/10.21834/ajbes.v3i10.85 


\subsection{Introduction}

Dayasari Residential College (DRC), located at the University of Malaya (UM) in Kuala Lumpur, is acknowledged as a naturally ventilated building with the most considerate implementation of bioclimatic design strategies that minimise the electricity consumption for lighting and cooling (Jamaludin et al., 2014). It showed amongst the lowest Energy Efficiency Index (34.52 $\mathrm{kWh} / \mathrm{m}^{2} /$ year) compared to other residential colleges in UM; which are in the range of 40 to $125 \mathrm{kWh} / \mathrm{m}^{2} /$ year (Jamaludin et al., 2013). Unfortunately, the lowest consumption of electricity is not the ultimate criteria for a successful implementation of bioclimatic design, especially if residents are to bare with unconducive environments. With regards to these conditions, POE is recognised as one of the ways to validate the successfulness of implementation of bioclimatic design strategies in providing a conducive indoor environment for the residents (Preiser, 1995). This study aims to promote sustainable living through the efficiency of natural ventilated residential college buildings in UM. The objective is to evaluate on performance criteria of building: the architectural elements, thermal comfort, indoor air quality, visual comfort, acoustic comfort and landscape elements, with the purpose of justifying the residents' perception and satisfaction with the implemented bioclimatic design strategies.

\subsection{Literature Review}

Bioclimatic concept and design strategies in buildings involve many disciplines, including human physiology, climatology and building physics (Olgyay, 1963). The principle behind the bioclimatic design is the understanding of the climatic factors of a site by analysing the influence of microclimate (solar radiation, sunshine, temperature, humidity, rainfall, wind velocity and direction) (Hyde, 2000). It is followed by a comparative analysis in assessing the climate data concerning thermal comfort and ends with the selection of climate responsive modification concept. This concept adopts a passive mode that includes built-form configuration and orientation, enclosure and facade design, daylight, natural ventilation, landscaping, etc., to optimise internal comfort conditions while reducing energy demands for electricity (Yeang, 2008; Zr \& Mochtar, 2013).

$\mathrm{POE}$ is defined as a process of evaluating buildings in a systematic and rigorous manner to indicate the satisfaction and comfort level needed by occupants as lessons learned to identify problems in indoor environments (Khalil \&Husin, 2009). Among plausible benefits of conducting the POE include applying design skills more effectively, improving commissioning process, user requirements and management procedures, providing knowledge of design guides and regulatory processes, and targeting of refurbishment (Whyte \&Gann, 2001). POE begins with planning, conducting and applying phase, can be done on three levels: indicative, investigative and diagnostic levels (Preiser, 1995). Each level has different techniques that can be assessed and utilized to the time frame, budget, manpower, aim and objectives that are to be achieved (Bordass \&Leaman, 2005). There is audit (using quantitative technical assessments), discussions (use discursive techniques such as workshops and interviews), questionnaires (methods that are used to adapt the procurement process to incorporate feedback in an organized manner) and packages (using probes). A critical evaluation using 
questionnaire system can be achieved when only most relevant issues are highlighted, rather than attempting to analyse everything and risk an overload of data (Niroumand et al., 2013).

There are four significant barriers to POE implementation: ownership, liability, lack of knowledge and progress (Hadjri \& Crozier, 2009). Riley et al. (2010) also highlighted culture as a barrier to POE process where the occupants may feel that moving into a new working environment is disruptive. Without any constructive database, the comparison cannot be carried out to identify the level of achievement (Mier et al., 2009). Therefore, the findings contribute to the establishment of a valuable database and systematic data collection system, particularly for residential college building in the tropics. It is inevitable that by providing opportunities for the improvement of building performance and the relationships of users' behaviour, able to provide a significant role in Malaysia's construction industry (Khalil et al., 2012).

\subsection{Methodology}

\section{Building description}

$\mathrm{DRC}$ is a low rise multi-residential building in UM campus, equipped with leisure areas, lounges, meeting rooms and laundry facilities, which can accommodate up to 847 residents. This naturally ventilated building was built in 1966 with $18,212.51 \mathrm{~m}^{2}$ of total floor area and $16.35 \mathrm{~m}^{2}$ of a typical room's floor area (Figure 1). The building's north-south orientation and surrounded by a square internal courtyard reduces glare and thermal gain while providing natural daylight and ventilation at the corridor and staircase areas. This encourages air circulation and daylight distribution inside the rooms through the fixed transom on top of the entrance door and the internal walls facing the courtyard. Only service areas (toilets, bathrooms, stores, staircases and balconies) are located at the west-east orientation. There are two types of windows: centre pivot and awning window, with standard float and tinted glasses, were installed in each room that able to channel outside wind inside. Correspondingly play a role as adjustable low inlets and high exhaust opening. The combination of windows and fixed transom encourages cross ventilation. To defuse the undesirable amount of solar radiation, there are large horizontal overhangs along the windows in each room, which projects significant shadow effects to the external walls. These design strategies, however, are not implemented at rooms on the ground floor. As the residential college was established more than five decades ago, most of the trees are matured with the huge canopies that are capable of covering large grounds and provide shading effects to the building (Figure 2). The figure ground study obtained the 61:39 ratio of soft and hard landscape area with 0.607 of Biotope Area Factor. 
Hazreena Hussein, H., \& Jamaludin, A.A. / Asian Journal of Behavioural Studies (AjBeS), 3(10) Mar / Apr 2018 (p.105-116)

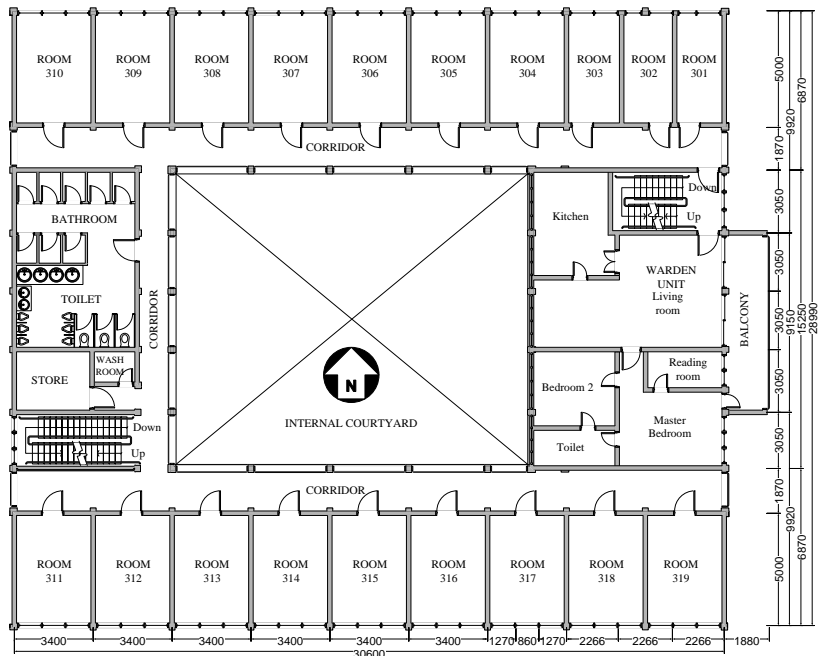

Figure 1: Typical floor plan of DRC building (Source: Author)

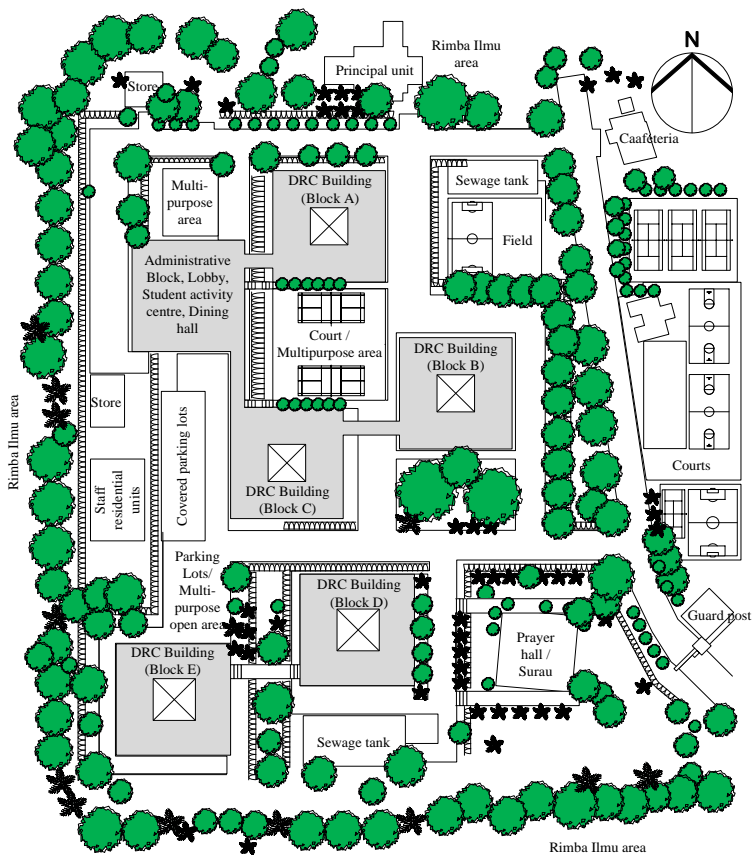

Figure 2: Site plan of DRC building (Source: Author) 


\section{Perception and satisfaction survey}

The questionnaire used in this study was adapted from Khalil and Husin (2009) work on POE of the indoor environment improvement in Malaysia. Five performance criteria (architectural element, visual comfort, acoustic comfort, landscape elements and a combination of thermal comfort and indoor air quality) with thirteen questions were enquired. To acquire for the residents' perception, the questionnaire was constructed on a five-point Likert scale, where each number responds to a specific scale:

- -2: very poor/very uncomfortable/much decreased/very hot/still air/too dark/very dissatisfied/very noisy

- -1: poor/uncomfortable/decreased/hot/inconspicuous still air/dark/dissatisfied/noisy

- $0:$ fair/neither/neutral/no changes,

- +1: good/comfortable/increased/cool/breezy/bright/satisfied/quiet

- +2: very good/very comfortable/much increased/very cool/very breezy/too bright/ very satisfied/very quiet.

The questionnaires were distributed to all occupants with the minimum number of feedbacks relying on $95 \%$ confidence level and $\pm 5 \%$ margin of error from the overall population. All the collected questionnaires were analysed by using a statistical software package, and the analysis was extended by way of comparing the percentage of respondents concerning the location of the room according to the floor levels.

\subsection{Results and Discussions}

A total of 266 out of 847 questionnaires were retrieved entirely filled by the respondents. Findings of perception and satisfaction survey are presented in Table 1.

The majority of the residents is in comfort level in all aspects, where more than $40 \%$ of them are 'satisfied' with the condition of the room and building. About $50.2 \%$ and $52.1 \%$ of the residents claimed that the residential building layout, which is the internal courtyard, and overall quality of the residential building is 'good', respectively. About $53.6 \%$ of the residents were 'comfortable' with the condition of the room while $49.4 \%$ claimed that the degree of work productivity has 'increased' considerably.

Regarding thermal comfort and indoor air quality, $43.6 \%$ of the residents felt 'cool' with indoor air temperature. About $46.2 \%$ claimed that the ventilation and air quality of the room are 'good' and $30.9 \%$ of them felt 'breezy' air movement in the room though without the aid of a mechanical fan. The building's orientation with a square internal courtyard offers a substantial potential for indoor thermal comfort as the ability of a courtyard to cool the surrounding built spaces by creating different pressure fields along the wind-flow axis (Rajapaksha et al., 2003). Also, the combination of two types of windows and fixed transom on top of the entrance door promotes cross ventilation. According to Haase and Amato (2006), the installation of a wall-mounted centre-pivoting window in a bedroom significantly improves the indoor air quality by increasing the efficiency of natural ventilation. Moreover, a shallow building with optimal orientation and a maximum of five floors is more applicable for exploiting the wind for natural ventilation, which well demonstrated in the studied building. 
On the visual comfort, majority of the residents $(48.5 \%)$ are 'satisfied' with the quality of light in the room. They claimed that the adequacy of both natural daylight $(40.9 \%)$ and artificial light (46.2\%) in the room are 'bright'. The application of daylighting in buildings improving human performance and well-being through daylights impact on aesthetics and vision (Leslie, 2003) while gives a significant saving on energy (Jamaludin et al., 2013). Lechner (2009) pointed out that large window area than walls, high ceilings with high windows, and O-shaped floor plans (fully enclosed) are the core design in providing daylighting in the building (Almhafdy et al., 2013). Additionally, the type of glazing and window gives major significance on the performance of natural light and thermal performance of adjacent space (Husin \& Harith, 2012).

A total of 266 out of 847 questionnaires were retrieved entirely filled by the respondents. Findings of perception and satisfaction survey are presented in Table 1.

The majority of the residents is in comfort level in all aspects, where more than $40 \%$ of them are 'satisfied' with the condition of the room and building. About $50.2 \%$ and $52.1 \%$ of the residents claimed that the residential building layout, which is the internal courtyard, and overall quality of the residential building is 'good', respectively. About $53.6 \%$ of the residents were 'comfortable' with the condition of the room while $49.4 \%$ claimed that the degree of work productivity has 'increased' considerably.

Regarding thermal comfort and indoor air quality, $43.6 \%$ of the residents felt 'cool' with indoor air temperature. About $46.2 \%$ claimed that the ventilation and air quality of the room are 'good' and $30.9 \%$ of them felt 'breezy' air movement in the room though without the aid of a mechanical fan. The building's orientation with a square internal courtyard offers a substantial potential for indoor thermal comfort as the ability of a courtyard to cool the surrounding built spaces by creating different pressure fields along the wind-flow axis (Rajapaksha et al., 2003). Also, the combination of two types of windows and fixed transom on top of the entrance door promotes cross ventilation. According to Haase and Amato (2006), the installation of a wall-mounted centre-pivoting window in a bedroom significantly improves the indoor air quality by increasing the efficiency of natural ventilation. Moreover, a shallow building with optimal orientation and a maximum of five floors is more applicable for exploiting the wind for natural ventilation, which well demonstrated in the studied building.

On the visual comfort, majority of the residents (48.5\%) are 'satisfied' with the quality of light in the room. They claimed that the adequacy of both natural daylight $(40.9 \%)$ and artificial light (46.2\%) in the room are 'bright'. The application of daylighting in buildings improving human performance and well-being through daylights impact on aesthetics and vision (Leslie, 2003) while gives a significant saving on energy (Jamaludin et al., 2013). Lechner (2009) pointed out that large window area than walls, high ceilings with high windows, and O-shaped floor plans (fully enclosed) are the core design in providing daylighting in the building (Almhafdy et al., 2013). Additionally, the type of glazing and window gives major significance on the performance of natural light and thermal performance of adjacent space (Husin \& Harith, 2012). 
Table 1: Findings of perception and satisfaction survey at DRC

\begin{tabular}{|c|c|c|c|c|c|}
\hline \multirow{2}{*}{ Performance criteria } & \multicolumn{5}{|c|}{ Likert scale / Residents' perceptions (\%) } \\
\hline & -2 & -1 & 0 & +1 & +2 \\
\hline \multicolumn{6}{|l|}{ Architectural elements } \\
\hline 1. Building layout (internal courtyard with open corridor) & 0.4 & 8.7 & 28.7 & $\begin{array}{l}\text { Good } \\
50.2\end{array}$ & 12.1 \\
\hline 2. Overall quality of the residential building & 1.1 & 6.0 & 28.7 & $\begin{array}{l}\text { Good } \\
52.1\end{array}$ & 12.1 \\
\hline 3. Overall comfort level of the room & 0.8 & 4.5 & 29.1 & $\begin{array}{l}\text { Comfortable } \\
53.6\end{array}$ & 12.1 \\
\hline $\begin{array}{l}\text { 4. Influence of room conditions on the degree of work } \\
\text { productivity } \\
\text { Thermal comfort and indoor air quality }\end{array}$ & 0.8 & 4.5 & 26.8 & $\begin{array}{l}\text { Increased } \\
49.4\end{array}$ & 18.5 \\
\hline 5. Thermal comfort/indoor air temperature in the room & 3.4 & 11.7 & 29.7 & $\begin{array}{l}\text { Cool } \\
43.6\end{array}$ & 11.7 \\
\hline 6. Ventilation and air quality of the room & 1.9 & 13.4 & 29.8 & $\begin{array}{l}\text { Good } \\
46.2\end{array}$ & 8.8 \\
\hline 7. Air movement in the room (without mechanical fan) & 13.7 & 22.1 & 26.7 & $\begin{array}{l}\text { Breezy } \\
30.9\end{array}$ & 6.5 \\
\hline \multicolumn{6}{|l|}{ Visual comfort } \\
\hline 8. Adequacy of natural daylight in the room & 4.2 & 12.0 & 34.4 & $\begin{array}{l}\text { Bright } \\
40.9\end{array}$ & 8.5 \\
\hline 9. Adequacy of artificial light in the room & 1.1 & 8.8 & 35.1 & $\begin{array}{l}\text { Bright } \\
46.2\end{array}$ & 8.8 \\
\hline 10. Quality of the lights in the room & 1.5 & 7.7 & 28.8 & $\begin{array}{l}\text { Satisfied } \\
48.5\end{array}$ & 13.5 \\
\hline \multicolumn{6}{|l|}{ Landscape elements } \\
\hline$\overline{\text { 11. Landscape quality at residential building }}$ & 1.5 & 8.0 & 33.7 & $\begin{array}{l}\text { Good } \\
48.7\end{array}$ & 8.0 \\
\hline 12. Landscape setting quality in the internal courtyard & 1.5 & 6.1 & 35.9 & $\begin{array}{l}\text { Good } \\
48.9\end{array}$ & 7.6 \\
\hline
\end{tabular}

Finally, majority of the residents claimed that the landscape quality in both surrounding residential building $(48.7 \%)$ and the internal courtyard (48.9\%) are 'good'. The presence of 'good' landscape quality influence the microclimate atmosphere and improve thermal comfort especially in a warm and humid climate (Thani et al., 2012; 2013). Tree canopies reduce air temperature while providing insulation effects for reducing the conductive heat gains and preventing unpleasant solar to access into the building especially during the mid-afternoon (Yeang, 2008; Misni, 2013). Additionally, the green infrastructure is a crucial part of the urban fabric that is highly perceived by residents contributing to their physical, cognitive and social well-being (Mansor et al., 2012).

Numerous different responses were discovered by comparing the results according to the positioning of the rooms (Figure 3). Dissatisfactions were mainly expressed by those who live on the ground floors, especially regarding their visual comfort, thermal comfort and indoor air quality elements. They rated one rate lower than the overall rate, as compared to those who live on the other floors. These could be due to various barriers either natural or manmade structures including the covered parking areas for motorcycle and trees with big crowns 
that prevent them from getting exposure to good daylighting and also from obtaining natural ventilation. Most of the respondents who live on the ground floor rated 'fair' for the ventilation and indoor air quality and all performance indicators of visual comfort. This differs from those who live at higher levels when the majority of them rated 'good' for all performance indicators of both visual comfort elements and thermal comfort and indoor air quality. Perhaps this is why higher-level rooms' occupants were reported to have their degree of work productivity 'increased' in comparison with 'no changes' noted for those occupying the ground floor.

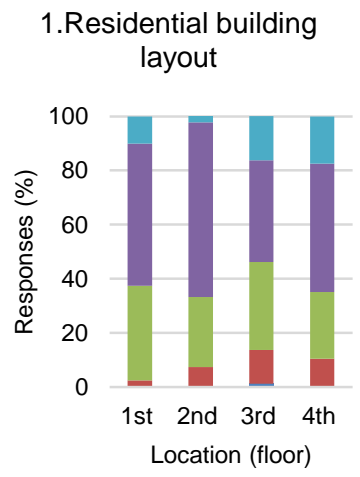

3.Overall comfort level of the room

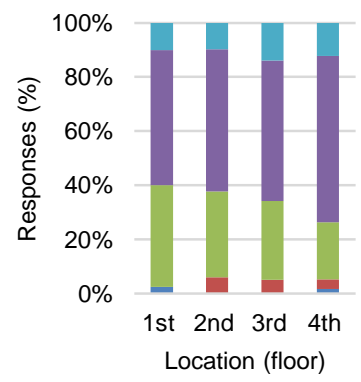

2.Overall quality of the residential building

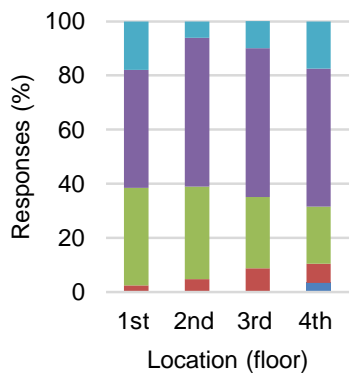

4.Influence on work productivity

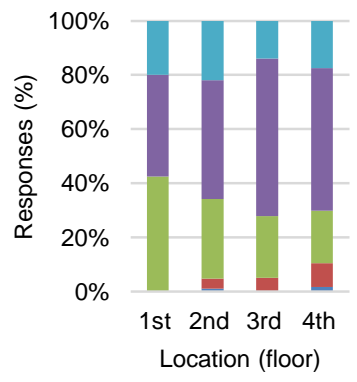




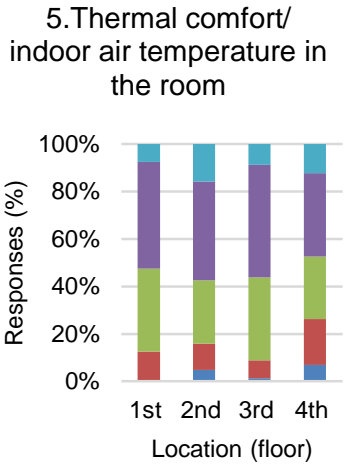

7.Air movement in the room

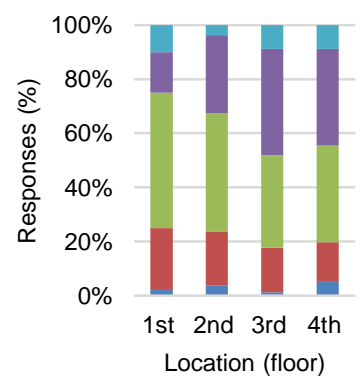

9. Adequacy of artifical light in the room

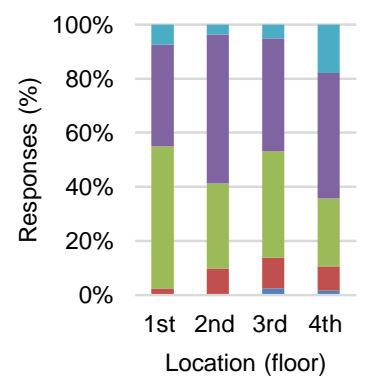

6.Ventilation and air quality of the room

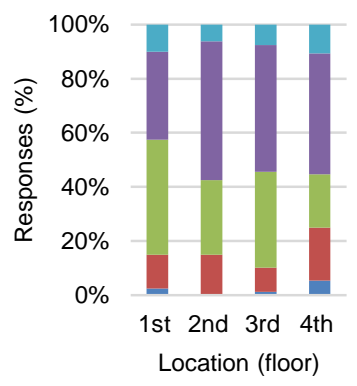

8.Adequacy of natural daylight in the room

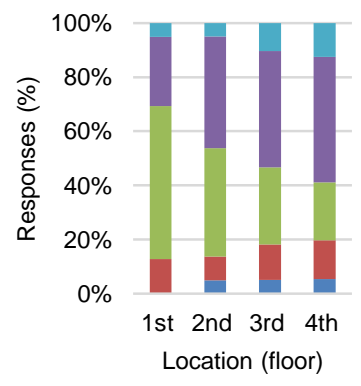

10.Quality of the lights in the room

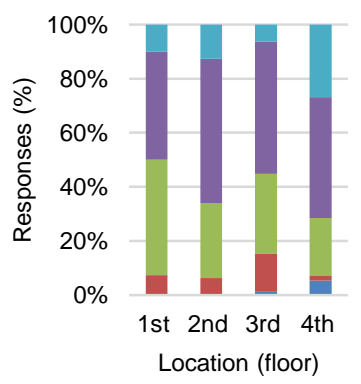




\begin{abstract}
11. Landscape quality at residential college area
\end{abstract}

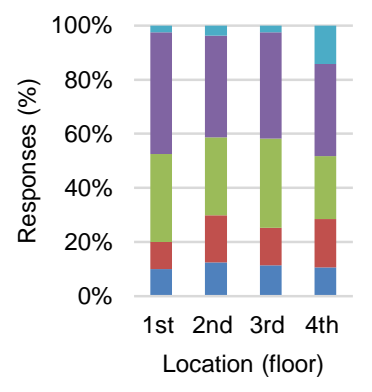

12. Landscape quality in the internal courtyard

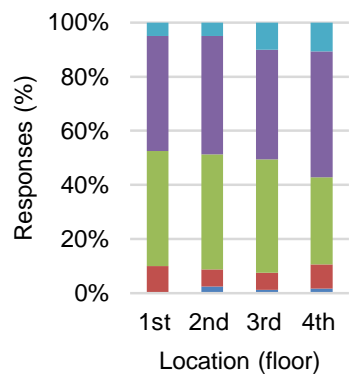

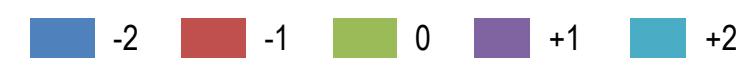

Figure 3: The result of satisfaction and perception survey according to the location of the rooms

Thus, it is necessary to determine the relationships between trees and buildings to optimise tree designs to gain access to good daylight and ventilation requirements (Hong et al., 2011). With regards to landscape, the majority of respondents on the second floor claimed that the landscape quality at both residential college areas and internal courtyards were 'good'.

\subsection{Conclusion}

The practice of bioclimatic design strategies at a residential college building has a positive impact on the perception and satisfaction level of the residents. Majority of the residents perceived that comfortable levels were achieved according to the architectural elements, thermal comfort and indoor air quality, visual comfort, acoustic comfort and landscape features. Therefore, the north-south building orientation and internal courtyard, the fixed transom on top of the entrance door and internal walls, centre pivot and awning windows, the wall opening in the room, large horizontal overhangs along the windows and good landscape setting should be highly considered in building design especially for residential college building towards promoting sustainable living.

The location of the room, rather than the gender aspect considerably influences the satisfaction and the perception level of respondents. Different responses gave by the residents according to the floor levels. These aspects should be highly considered in implementing the improvement measures to ensure the comfort standards of the room towards sustainable transformation, especially in urban area. The internal courtyard should be fully optimised while trees in the landscape; either in the internal courtyard or surrounding residential buildings, must appropriately be designed to meet sufficient daylight and 
ventilation requirements.

As recommendations, POE should integrate, firstly, more than one of the data collection methods. The combination of questionnaire survey, focus group, documentary analysis and monitored data, which form a methodological triangulation, will be able to enhance the credibility and persuasiveness of a study. This is by giving a more detailed picture of the situation that facilitates the validation of data through cross verification from more than two sources in the study. Secondly, POE should integrate the number of respondents that must exceed the minimum number of feedbacks, which relying on $95 \%$ of the confident level and $\pm 5 \%$ margin of error from the overall population. Therefore, the number and scope of questions must be adequately designed with regards to the research objectives. Thirdly, POE should use language and phrases that are easy to be understood in getting a positive number of feedbacks. For comparison, other residential colleges should be included especially with the different application of bioclimatic design strategies.

\section{Acknowledgement}

Thank you to Dayasari RC for their permission to carry out POE. This analysis was financially supported by the Institut Pengurusan dan Pemantauan Penyelidikan, under BKP Grant (BK010-2015).

\section{References}

Almhafday, A., Ibrahim, N., Ahmad, A. A., \& Yahya, J. (2013). Analysis of courtyard functions and its design variants in the Malaysian Hospital. Procedia - Social and Behavioral Sciences, 105, 171-182.

Bordass, B., \& Leaman, A. (2005). Phase 5: Occupancy-post occupancy evaluation. In W. F. E. Preiser, \& J. C. Vischer (Eds.), Assessing building performance (pp.72-79). Oxford: Elsevier Butterworth-Heinemann.

Haase, M., \& Amato, A. (2006). Sustainable facade design for zero energy buildings in the tropics. The 23rd Conference on Passive and Low Energy Architecture. Retrieved January 12, 2013, from Universite De Geneve website: http://www.unige.ch/cuepe/html/plea2006/Vol1/PLEA2006_PAPER509.pdf.

Hadjri, K., \& Crozier, C. (2009). Post-occupancy evaluation: Purpose, benefits and barriers. Facilities, 27, 21-33.

Hong, B., Lin, B., Hu, L., \& Li, S. (2011). Optimal tree design for sunshine and ventilation in residential district using geometrical models and numerical simulation. Building Simulation, 4, 351-363.

Husin, S. N. F. S., \& Harith, Z. Y. H. (2012). The performance of daylight through various type of fenestration in residential building. Procedia - Social and Behavioral Sciences, 36, 196-203.

Hyde, R. (2000). Climate responsive design: A study of buildings in moderate and hot humid climates. New York: E \& FN Spon.

Jamaludin, A. A., Hussein, H., Ariffin, A. R. M., \& Keumala, N. (2014). A study on different natural ventilation approaches at a residential college building with the internal courtyard arrangement. Energy and Building, 72, 340352. 
Jamaludin, A. A., Mahmood, N. Z., Keumala, N., Ariffin, A. R. M., \& Hussein, H. (2013). Energy audit and prospective energy conservation - Studies at a residential college buildings in a tropical region. Facilities, 31, 158-172.

Khalil, N., \& Husin, H. N. (2009). Post occupancy towards indoor environment improvement in Malaysia's office buildings. Journal of Sustainable Development, 2, 186-191.

Khalil, N., Husin, H. N., \& Nawawi. A. H. (2012). An analytical literature: Strategic improvement of sustainable building performance tool for Malaysia's Higher Institutions. Procedia - Social and Behavioral Sciences, 36, 306313.

Lechner, N. (2009). Heating, cooling, lighting: Sustainable design methods for architects. (3rd ed.).New Jersey: John Wiley \& Sons.

Leslie, R. P. (2003). Capturing the daylight dividend in buildings: why and how?. Building and Environment, 38, 381 385.

Mansor, M., Said, I., \& Mohamad, I. (2012). Experiential Contacts with Green Infrastructure's Diversity and Wellbeing of Urban Community. Procedia - Social and Behavioral Sciences, 49, 257-267.

Mier, I. A., Garb, Y., Jiao, D., \&Cicelsky, A. (2009). Post-occupancy evaluation: An inevitable step toward sustainability. Advances in Building Energy Research, 3, 189-220.

Misni, A. (2013). Modifying the outdoor temperature around single-family residences: The influence of landscaping. Procedia - Social and Behavioral Sciences, 105, 664-673.

Niroumand, H., Zain, M. F. M., \& Jamil, M. (2013). Building evaluation based on sustainable development using questionnaire system. Procedia - Social and Behavioral Sciences, 89, 454-460.

Olgyay, V. (1963). Design with climate: Bioclimatic approach to architectural regionalism. Princeton, NJ: Princeton University Press.

Preiser W. F. E. (1995). Post-occupancy evaluation: How to make buildings work better. Facilities, 13, 19-28.

Rajapaksha, I., Nagai, H., \& Okumiya, M. (2003). A ventilated courtyard as a passive cooling strategy in the warm humid tropics. Renewable Energy, 28, 1755-1778.

Riley, M., Kokkarinen, N., \& Pitt, M. (2010). Assessing post occupancy evaluation in higher education facilities. Journal of Facilities Management, 8, 202-213.

Thani, S. K. S. O., Mohamad, N. H. N., \& Abdullah, M. S. (2013). The influence of urban landscape morphology on the temperature distribution of hot-humid urban centre. Procedia - Social and Behavioral Sciences, 85, 356-367.

Thani, S. K. S. O., Mohamad, N. H. N., \& Idilfitri, S. (2012). Modification of urban temperature in hot-humid climate through landscape design approach: A review. Procedia - Social and Behavioral Sciences, 68, 439-450.

Whyte, J., \& Gann, D. M. (2001). Closing the loop between design and use: Post-occupancy evaluation. Building Research and Information, 29, 460-462.

Yeang, K. (2008). Ecodesign: A manual for ecological design. London, UK: John Wiley \& Son Ltd.

Zr, D. L., \& Mochtar, S. (2013). Application of bioclimatic parameter as sustainability approach on multi-story building design in tropical area. Procedia Environmental Sciences, 17, 822-830. 